\title{
Erratum to: Strahlentherapie und Onkologie, Volume 186 (No. 1)
}

\author{
Erratum to: \\ Strahlenther Onkol 2010;186:1-6 \\ (DOI 10.1007/s00066-009-2026-4) \\ Strahlenther Onkol 2010;186:7-17 \\ (DOI 10.1007/s00066-009-1995-7) \\ Strahlenther Onkol 2010;186:18-23 \\ (DOI 10.1007/s00066-009-2025-5) \\ Strahlenther Onkol 2010;186:24-9 \\ (DOI 10.1007/s00066-009-2049-x) \\ Strahlenther Onkol 2010;186:30-5 \\ (DOI 10.1007/s00066-009-2037-1) \\ Strahlenther Onkol 2010;186:36-9 \\ (DOI 10.1007/s00066-009-2019-3) \\ Strahlenther Onkol 2010;186:46-52 \\ (DOI 10.1007/s00066-009-2023-7)
}

There were, due to a technical problem, errors in several References of seven articles published in this journal's issue No. 1/2010. Please note the corrected References below:

Dittmann K, Mayer C, Rodemann HP. Nuclear EGFR as Novel Therapeutic Target. Insights into Nuclear Translocation and Function. Strahlenther Onkol 2010;186:1-6 (DOI 10.1007I s00066-009-2026-4)

37. Marquardt F, Rodel F, Capalbo G, et al. Molecular targeted treatment and radiation therapy for rectal cancer. Strahlenther Onkol 2009;185:371-8.

42. Niyazi M, Marini P, Daniel PT, et al. Efficacy of a triple treatment with irradiation, agonistic TRAIL receptor antibodies and EGFR blockade. Strahlenther Onkol 2009;185:8-18.

Mücke R, Seegenschmiedt MH, Heyd R, Schäfer U, Prott F-J, Glatzel M, Micke O, German Cooperative Group on Radiotherapy for Benign Diseases (GCG-BD). [Radiotherapy in Painful Gonarthrosis. Results of a National Patterns-of-Care Study] Strahlentherapie bei schmerzhafter Kniegelenkarthrose (Gonarthrose). Ergebnisse einer deutschen Patterns-of-Care-Studie. Strahlenther Onkol 2010;186:7-17 (DOI 10.1007/s00066-0091995-7)

21. Majdoub FE, Brunn A, Berthold F, et al. Stereotactic interstitial radiosurgery for intracranial Rosai-Dorfman disease. A novel therapeutic approach. Strahlenther Onkol 2009;185:109-12.

Adamietz B, Schulz-Wendtland R, Alibek S, Uder M, Sauer R, Ott O, Keilholz L. Calcifying Tendonitis of the Shoulder Joint. Predictive Value of Pretreatment Sonography for the Response to Low-Dose Radiotherapy. Strahlenther Onkol 2010;186:18-23 (DOI 10.1007/s00066-009-2025-5)

14. Janssen S, Karstens JH, Sauer R. Endokrine Orbitopathie - Wie effektiv ist die Strahlentherapie? Strahlenther Onkol 2009;185:61-2.
Heyd R, Dorn AP, Herkströter M, Rödel C, MüllerSchimpfle M, Fraunholz I. Radiation Therapy for Early Stages of Morbus Ledderhose. Strahlenther Onkol 2010; 186:24-9 (DOI 10.1007/s00066-009-2049-x)

11. El Majdoub F, Brunn A, Berthold F, et al. Stereotactic interstitial radiosurgery for intracranial Rosai-Dorfman disease. A novel therapeutic approach. Strahlenther Onkol 2009;185:109-12.

15. Heyd R, Buhleier T, Zamboglou N. Radiation therapy for prevention of heterotopic ossification about the elbow. Strahlenther Onkol 2009;185:506-11.

17. Janssen S, Johann H, Karstens H. Endokrine Orbitopathie - Wie effektiv ist die Strahlentherapie. Strahlenther Onkol 2009;185:61-2.

Wolff HA, Gaedcke J, Jung K, Hermann RM, Rothe H, Schirmer M, Liersch T, Herrmann MKA, Hennies S, RaveFränk M, Hess CF, Christiansen H. High-Grade Acute Organ Toxicity During Preoperative Radiochemotherapy as Positive Predictor for Complete Histopathologic Tumor Regression in Multimodal Treatment of Locally Advanced Rectal Cancer. Strahlenther Onkol 2010;186:30-5 (DOI 10.1007/s00066-0092037-1)

31. Vorwerk $\mathrm{H}$, Liersch $\mathrm{T}$, Rothe $\mathrm{H}$, et al. Gold markers for tumor localization and target volume delineation in radiotherapy for rectal cancer. Strahlenther Onkol 2009;185:127-33.

Mizumoto M, Nakayama H, Tokita M, Sugahara S, Hashii H, Sakae T, Tsuboi K, Sakurai H, Tokuuye K. Technical Considerations for Noncoplanar Proton-Beam Therapy of Patients with Tumors Proximal to the Optic Nerve. Strahlenther Onkol 2010;186:36-9 (DOI 10.1007/s00066-009-2019-3)

2. Bekkering GE, Rutjes AW, Vlassov VV, et al. The effectiveness and safety of proton radiation therapy for indications of the eye. A systematic review. Strahlenther Onkol 2009;185:211-21.

28. Wang C, Nakayama H, Sugahara S, et al. Comparisons of dose-volume histograms for proton-beam versus 3-D conformal X-ray therapy in patients with stage I non-small cell lung cancer. Strahlenther Onkol 2009;185:231-4.

Geinitz H, Thamm R, Scholz C, Heinrich C, Prause N, Kerndl S, Keller M, Busch R, Molls M, Zimmermann FB. Longitudinal Analysis of Quality of Life in Patients Receiving Conformal Radiation Therapy for Prostate Cancer. Strahlenther Onkol 2010;186:46-52 (DOI 10.1007/s00066-009-2023-7)

10. Goldner G, Bombosch V, Geinitz H, et al. Moderate risk-adapted dose escalation with three-dimensional conformal radiotherapy of localized prostate cancer from 70 to $74 \mathrm{~Gy}$. First report on 5-year morbidity and biochemical control from a prospective Austrian-German multicenter phase II trial. Strahlenther Onkol 2009;185:94-100.

24. Pinkawa M, Piroth MD, Asadpour B, et al. Neoadjuvant hormonal therapy and external-beam radiotherapy versus external-beam irradiation alone for prostate cancer. A quality-of-life analysis. Strahlenther Onkol 2009;185:101-8.

Strahlenther Onkol 2010 DOI 10.1007/s00066-010-7001-6 Published Online: January 28, 2010 